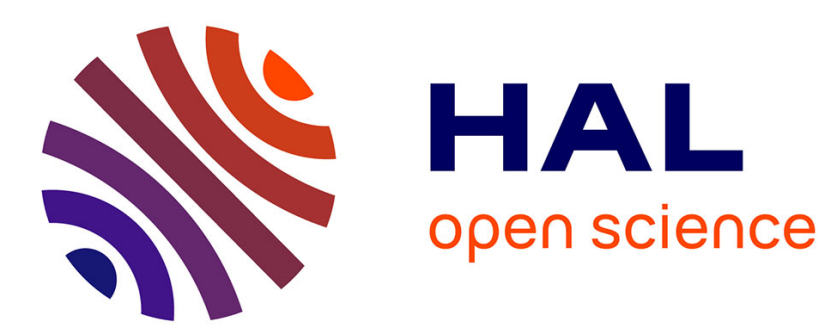

\title{
Is the game lost in advance? Being a high-performance coach and preserving family life
}

Hélène Joncheray, Fabrice Burlot, Mathilde Julla-Marcy

\section{To cite this version:}

Hélène Joncheray, Fabrice Burlot, Mathilde Julla-Marcy. Is the game lost in advance? Being a highperformance coach and preserving family life. International journal of Sports Science and Coaching, 2019, 14 (4), pp.453-462. 10.1177/1747954119860223 . hal-02269050

\section{HAL Id: hal-02269050 https://hal-insep.archives-ouvertes.fr/hal-02269050}

Submitted on 22 Aug 2019

HAL is a multi-disciplinary open access archive for the deposit and dissemination of scientific research documents, whether they are published or not. The documents may come from teaching and research institutions in France or abroad, or from public or private research centers.
L'archive ouverte pluridisciplinaire HAL, est destinée au dépôt et à la diffusion de documents scientifiques de niveau recherche, publiés ou non, émanant des établissements d'enseignement et de recherche français ou étrangers, des laboratoires publics ou privés. 


\title{
Is the game lost in advance? Being a high-performance coach and preserving family life

\author{
Hélène Joncheray ${ }^{1,2} \mathbb{\infty}$, Fabrice Burlot $^{1}$ and \\ Mathilde Julla-Marcy ${ }^{3}$
}

\begin{abstract}
This article examines how high-performance sport coaches combine their professional and family lives. To address this issue, semi-structured interviews were conducted with 4 I French coaches ( 8 females, 33 males) involved in the preparation of the French teams for the Olympic Games in Rio (2016), Pyeongchang (2018) and/or Tokyo (2020). The results show that all the coaches interviewed are engaged in a passionate relationship with their job. For some coaches, this commitment has an impact on their family life. Three groups of coaches stand out: (i) a majority of coaches who are unable to preserve their family life, (ii) coaches who maintain a distance from their profession and preserve their family life, (iii) coaches who have or have not preserved their family life and who position themselves as actors wishing to do everything possible to preserve the family life of the coaches they supervise. Thus, these results highlight, for some coaches, difficulties in combining professional and family life. For others, family life is a protection for engagement in a passionate profession. These data can provide useful information for sport organizations in charge of coaches.
\end{abstract}

\section{Keywords}

Elite sport, Olympic Games, professionalism, stress, work-life balance

\section{Introduction}

Sociological surveys show that, in an important context of international competition, Olympic performance is strongly linked to the socio-cultural environment in which those involved in the performance - most accomplished sport coaches and athletes, in particular evolve. ${ }^{1-3}$ In the same way that the daily life of top athletes raises, ${ }^{4-6}$ issues about the profession of a toplevel coach $^{\mathrm{a}}$ are of interest: ${ }^{7-9}$ How do these very few coaches build part of their success? ${ }^{10}$ This occupation requires involvement in a career where the pressure of performance $^{11,12}$ is very high. ${ }^{13,14}$ This is a job with severe time constraints, ${ }^{15-18}$ along with unusual schedules: "Most occupations within the sport industry require long, non-traditional hours (i.e. nights and weekends), and often extensive travel" (Dixon and Bruening, ${ }^{1}$ p.230). One of the difficulties faced by coaches is, therefore, to distinguish between their professional and their family life. As Dixon and Bruening noted, "obstacles to work-family balance have been documented (...), demonstrating the relevance of the workfamily interface within the sport industry as a whole" (Dixon and Bruening, ${ }^{1}$ p.227). This difficulty affects coaches in different countries. ${ }^{8,13,18-25}$ Thus, a large majority of coaches, regardless of their culture, seem to face difficulties in combining work and family life. However, little has been published on this subject on coaches in France. ${ }^{26,27}$ Moreover, while most of the work deals with this question from the point of view of the difficulties, fewer people go beyond explaining this observation in order to understand the adaptations put in place to deal with this situation. It is therefore a

Reviewers: Mike Callan (University of Hertfordshire, United Kingdom) Geoffery Kohe (University of Kent, United Kingdom) Leisha Strachan (University of Manitoba, Canada)

'Laboratoire Sport, Expertise et Performance (EA 7370), INSEP, Paris, France

${ }^{2}$ Institut des Sciences du Sport-Santé de Paris (EA 3625), Université Paris Descartes, Paris, France

${ }^{3}$ Institut des Sciences Sociales du Politique (UMR 7220), Université Paris Nanterre, Paris, France

Corresponding author:

Hélène Joncheray, Laboratoire Sport Expertise et Performance (EA 7370), INSEP, II Avenue du Tremblay, 75012 Paris, France. Email: Helene.JONCHERAY@insep.fr 
question of shifting the focus to consider family life not only as antagonistic to professional commitment, but also as an alert, or even a protection, in the face of professional over-commitment. This research is part of a broader reflection on the cult of performance. ${ }^{28}$ The aim is to discuss the limits of professional identity in the world of sports, ${ }^{9}$ as has already been the case in art professions. ${ }^{29,30}$ This article suggests the study of elite French coaches and (i) the way they reconcile, on a daily basis, ${ }^{31}$ their passion for high-performance coaching and their family life, (ii) the difficulties they face but also (iii) the forms of protection which, in response to this situation, make it possible to maintain a balanced life.

\section{Theoretical frame}

This article is based on the interactionist theory developed by the Chicago School and then by Goffman, ${ }^{31-33}$ among others. To understand the dynamics of interactions and strategies in the study of sport, Goffman's model is particularly applicable, specifically in his " ability to capture social life", (Birrell and Donnelly, ${ }^{34}$ p.51). This paradigm makes it possible to study the different experiences of individuals' involvement in their daily life. Those experiences are also dependent on the institutions in which they operate. However, these macro sociological elements will not be directly addressed in this article. As a matter of fact, the interactionist approach has been used to study both (i) the unlimited involvement of coaches in a passionate profession and (ii) the reciprocal impact between professional involvement and family life. By focusing on key actors in the world of sport - high-level coaches - the objective of this article is to study and analyze interactions within two social spheres, namely professional life and family life. Indeed, we consider coaches as social actors who "have a margin of autonomy that allows them to internalize, refuse or negotiate the definition of their status. They thus participate, at least to some extent, in the construction of their social and personal identity"' (Paugam, ${ }^{35}$ p.29). In this way, we wish to explore how coaches negotiate and redefine their identities within the related and potentially conflicting social spheres of work and family. 1,36,37

\section{Professional commitment in a passionate profession}

By defining themselves mainly around a strong commitment to a passionate profession, ${ }^{38}$ sport coaches convey a positive social value ${ }^{39}$ of their professional identity. This is what Goffman calls the social face, ${ }^{39}$ which he defines as the way the identities of individuals are categorized by society, through what is thought and said about them. In this sense, according to Goffman, ${ }^{39}$ a person's social face would be their most valuable asset.
But this attribution of an identity would require the individuals to be worthy of it, at the risk otherwise that it is not any more attributed to them. In this article, we want to understand if, through their professional ambition, these passionate individuals demonstrate, at the same time, (i) a strong character in the sense that they would put everything in place to accomplish the professional tasks assigned them; ${ }^{39}$ (ii) then, if they commit themselves without counting and with courage: Do these individuals identify all the obstacles to be overcome? Does their determination inspire them to move forward at all costs to achieve their goals? ${ }^{39}$ Giving a good self-image by giving a good image of one's profession can be limiting in the construction of each individual's identity. As a matter of fact, the attributes granted to individuals can constitute strong social constraints because they define expectations with respect to (the image of) their professions. However, to perform, we wonder if these social constraints can go as far as placing individuals in a cell monitored by themselves. ${ }^{39} \mathrm{We}$ make the assumption that preserving a certain form of personal well-being, while remaining effective, ${ }^{40}$ passionate coaches implement different types of strategies in their professional and family commitments. ${ }^{41,42}$

\section{The downside: The impact of professional engagement on family life}

The coaching profession requires a significant time. ${ }^{43,44}$ The demands of the social world in which these coaches live have increased dramatically. The generalization of world rankings in the form of ranking lists ${ }^{45}$ has led to a densification of sports calendars. Deadlines are multiplying and reducing preparation periods. This creates greater needs for the daily time availability of coaches. As a result, training hours and preparation courses are increasing. And, the training is becoming more complex with the resurgence of specialists whose management must also be ensured. These consequences can be detrimental to the time management of high-level coaches, ${ }^{46}$ particularly in their family lives. ${ }^{47}$ This race for performance ${ }^{28}$ is a perfect illustration of Rosa's work $^{48}$ on social acceleration of time. For coaches, it means an acceleration of their pace of $\operatorname{life}^{15}$ and a necessary reflection on the time devoted to family. ${ }_{50}^{49}$ This can have consequences in terms of alienation to work if no institutional regulation is put in place. ${ }^{9}$ Indeed, the person may be more or less able to distance themself from their professional life, i.e. to be able to be opposed to the institution and willing to react to regain their balance. ${ }^{32}$ In this sense, there are different types of strategies for combining work and family life.

Thus, some individuals define themselves in terms of a single identity: professional identity. They share a sense of obligation, of social engagement. ${ }^{32}$ And, they 
explain that it is difficult to preserve a personal territory. ${ }^{32}$ In the same way that Goffman describes illness in Asylums,${ }^{32}$ the coaching profession, also institutionalized in a social space, would impose major determinations of servitude. ${ }^{32}$ With a unique identity, these coaches are frequently in conflict situations between professional and family life. As Dixon and Bruening explain, ${ }^{1}$ in certain sporting environments, sacrificing one's personal and family life for one's profession can go so far as to be evidence of a flawless and indispensable commitment to perform. However, these vulnerable coaches ${ }^{51}$ who may seem to be weak actors ${ }^{32}$ participate in defining the standards of engagement in a profession valued by the sports institution. The ideal and necessary commitment to work to succeed is thus defined by coaches who work very long hours and constantly travel for competitions. ${ }^{52}$

On the other hand, by trying at best to take a "role distance" from their profession, some individuals engaged in a passionate profession succeed in not losing face $^{32}$ in their family identity. Sometimes by departing from the role assigned by the institution, and by making secondary adaptations, these individuals preserve their family life in their identity construction: The desire of these individuals to distance themselves from their profession is not incidental. It is an integral part of their identity. ${ }^{32}$ Being a father or mother as well as $\operatorname{coach}^{52-54}$ can help some high-performance sports coaches to make additional adaptations that maintain a balance between their professional and family. ${ }^{55,56}$

\section{Methods}

\section{Protocols}

This survey is based on 41 interviews with Olympic coaches ( 8 females, 33 males), conducted between February and July 2018. Semi-structured interviewing is the most appropriate methodological tool for an analysis based on an interactionist framework. It gives access to both (i) objective elements relating to the organization of the profession and career development and (ii) statements and representations by coaches about themselves and their profession, which contribute to defining their identities.

\section{Sample}

The sample was constructed to be the most representative of the total population of French elite coaches involved in the preparation of the French teams for the Olympic Games in Rio (2016), Pyeongchang (2018) and/or Tokyo (2020). This sample was established from the lists of coaches accredited for the Olympic Games provided by the Ministry of Sports. There is no official list of top coaches in France, and it is difficult to give an order of magnitude to this professional sector. There are several professional statuses: some are public servants in the Ministry of Sports, others are detached physical education and sports teachers, still others have private contracts, not to mention coaches in professional sports clubs (football, rugby, handball, basketball, volleyball, etc.). In 2017, there were 346 national coaches in charge of French teams and 1187 national and regional technical advisers who participate in the federal sports coaching policy, some of them with the Olympic teams. ${ }^{\text {b }}$ The sample of the 41 coaches interviewed was based on the Olympic discipline, the performance, the gender and the training place. The choice of these sampling criteria made it possible to create a heterogeneous group, more or less in the spotlight: ${ }^{33}$ four coaches are under 35 years, 25 are between 35 and 50 and 12 are over 50. Regarding the duration of their commitment as high-level coaches: 11 have been committed for less than 8 years, 20 have an experience of 8 to 10 years and 9 of them have been coaching for over 16 years. Among the coaches interviewed, 25 are married or live with a partner and 31 have at least one child. To preserve the anonymity of the coaches interviewed, a limited number in high performance, only the Olympic disciplines and the corresponding number of coaches are given: archery (three coaches), basketball (two coaches), beach volleyball (two coaches), boxing (two coaches), cycling (one coach), canoe kayaking (two coaches), fencing (three coaches), golf (one coach), gymnastics (three coaches), handball (one coach), horseback riding (one coach), judo (three coaches), rowing (one coach), rugby (one coach), skiing (one coach), swimming (four coaches), table tennis (one coach), taekwondo (one coach), track and field (six coaches), weightlifting (one coach), wrestling (one coach). Similarly, the comments are identified only by borrowed names and discipline is not indicated.

\section{Tool and data collection}

The interviews focused on the working conditions of high-level coaches in France. The intent of the interviews was to discuss a number of topics related to (i) the sporting and professional career, (ii) the functions of a coach, (iii) the profession of a coach in relation to other staff members, (iv) the function of a coach in relation to high-level athletes, (v) training, (vi) changes and innovations and (vii) working conditions. The interviews, lasting 1 to $3 \mathrm{~h}$, were recorded and transcribed. A thematic analysis was carried out according to an iterative process of going back and forth between initial research questions, interview content and contributions of the sociological literature. Each interview led to the preparation of a summary sheet by the interviewer indicating the main information illustrated by verbatim quotations according to four main themes and 12 
sub-themes: (i) career (previous career/various positions held/current position), (ii) actual job demands (daily tasks and assignments/relations with other highlevel staff members/relations with high-level athletes), (iii) training/innovation (acquisition of new knowledge and skills/innovations and changes in training) and (iv) working conditions (changes in the profession/perceptions of the profession/coordination professional life social life/projection in the future). Collective meetings of all survey participants were held at various stages of the interview campaign. The purpose was to compare the contents of the interviews by noting the themes addressed in each one, in order to suggest convincing analytical approaches while paying attention to the variety of situations and cases encountered. A return to the interviews was made in a second stage in the preparation of this article to incorporate relevant quotations. The three authors of the article had all previously participated in surveys on various topics related to high-performance sport and therefore have in-depth knowledge of this environment obtained through observations and discussions, formal and informal. This facilitated access to elite coaches and made it easier for them to express themselves, ensuring long and rich interviews at the same time as verifying and controlling the content of the statements made. The data were only translated for this article.

The results are presented in two parts: The first part shows that all the coaches interviewed are engaged in a passionate relationship with their job. The second part looks at the different strategies implemented by coaches with regard to this professional commitment and their family life.

\section{Results and discussion}

Data analysis shows that all the coaches interviewed are engaged in a passionate relationship with their job. For some of them, this commitment has an impact on their family life. Three groups of coaches stand out ${ }^{21}$ (i) coaches who are unable to preserve their family life, (ii) coaches who maintain a distance from their professional life and preserve their family life, (iii) coaches who have or have not preserved their family life and who position themselves as actors wishing to do everything possible to preserve the family life of the coaches they supervise. Thus, while some coaches explain that they have difficulty combining professional and family life, for others, family life is a protection for their commitment to a passionate profession.

\section{A passionate profession and an unlimited commitment}

Passion for coaching. In the same way as Purdy et al. ${ }^{9}$ observe, all the coaches interviewed, without exception, highlight the fact that they are passionate about their profession: "I am a passionate person (...) I exercise a passionate profession"' (Hugo), "we are completely passionate" (Lou), "it is a passionate profession" (Mickaë 1). Coaches go so far as to argue that their pro- fession is not, or is more than a profession: It is a pas- sion. ${ }^{57}$ They feel very lucky to make their passion their profession: "Out of my passion, I made it my profes- sion (...). I have always really considered us to be ultra privileged (...). Being a coach is good like caviar' (Christophe). These coaches explain that they feel they have a privileged professional position. $^{58}$

The fact of making your passion your profession is often associated with a privileged relationship with the sport: "I always say: 'If you scratch my skin, under my skin, it will be written'[i.e. sport]'. I breathe [i.e. sport]. I wouldn't want to do anything else' (George). This relationship with the sport discipline can be very strong:

What matters is the discipline (.. .) That's what people don't understand, 'Who cares about the athlete' if I can put it that way. The interest is discipline, we like our discipline and we want it to be valued: if it is a German, if it is a Spanish who wins, we don't care. (Serge)

Coaches are definitely committed to the discipline they coach. A sense of loyalty ${ }^{59}$ towards this discipline is the basis of their unwavering commitment. ${ }^{60}$ This commitment/passion is partly sparked by the sports institution. $^{61}$

An unlimited commitment to perform. The coaching profession is also perceived as a profession that "never stops", where

the time spent at work is 7 days a week (.. .). Holidays don't mean anything. The only time I can get out of it a little bit is once I have seen the essence of what I have to do, so my mind is free (.. .). I am perceived as someone who does not have much time (.. .). But, anyway, that's sport, whatever the discipline. At some point you cannot project yourself on aspects of daily life like everyone else. (Sandra)

This uncompromising commitment to a passionate profession $^{57,62}$ seems to be a fatality for some coaches, justified by an inability to do otherwise: "It is a passionate profession, you never want to say no" (Hugo). Another coach explains that he is always "in, all the way (...). I burn myself sometimes, but I don't know how else to do it. So I try to watch myself, not to go as far as the crash"' (Christophe).

This commitment requires a strong character ${ }^{39}$ to accomplish the task, that is, to obtain one or even several medals: "We are completely passionate, fully into 
it, you don't protect yourself, you go all the way, you don't pay attention to your career, you pay attention to nothing. You go for it" (Lou). Coaches also demonstrate courage ${ }^{39}$ by a level of commitment related to the pursuit of performance ${ }^{11}$ at all costs. However, as this coach says, it is sometimes difficult to limit this commitment:

as if all of a sudden I had the feeling that I would master everything (...). Yes, all of a sudden I thought I was God, I thought I had such a good command of performance that if I did that, the girls would get a medal, which was ridiculous (...). Suddenly, I lost it, we had to get the medal, as people couldn't do it, I was going to do it. (Hugo)

This passion for the profession, combined with a feeling of obligation to be committed to performing, makes the situation complex for coaches. Some suffer from the delay it causes in the eyes of others who believe this profession is idyllic: "We are thought of in an idyllic situation while we are on the verge of burnout in very difficult working conditions but we love our profession"'(Mickaë1).

\section{Coaching profession and family life}

Being a national coach is clearly identified as a profession that requires a high investment of time, which can consequently limit the time devoted to one's family. As Graham and Dixon ${ }^{43}$ have explained, the high expectations in terms of time devoted to the coaching profession create a challenge as to the availability of engagement in family life. This is what this coach, who has just started in her new role as national coach, says: "I'm going to have to announce this at home to get started: my imminent disappearance" (Brigitte). For this reason, some of the coaches interviewed explain that it is not possible to have a long career without having an impact on family life: ${ }^{63}$ "I believe that you cannot have a career in coaching all your life", (Alexander). This theme, often addressed spontaneously by coaches, shows the centrality of this issue for them and questions relationships within family life. ${ }^{49}$

Passion for coaching takes precedence over family life: From washing machine to divorce. The majority of coaches interviewed explained that they had encountered difficulties in preserving personal territory. ${ }^{32}$ The passion for their profession has turned into an obligation of commitment (social engagement), in a unique identity, that of a coach, which has taken precedence over their family identity: "I experienced this as an opportunity so I invested myself and even overinvested in my profession. And then, you see, I didn't have the clarity to see that
I was finally neglecting my family life. So it exploded" (Pierre). For these coaches, their investment jeopardizes their family balance, by a more or less conscious renunciation of the time dedicated to the family: ${ }^{64}$

It has been getting worse and worse. At first, I had time, I could settle down (.. .). Gradually, it became a washing machine in which I have the feeling that I was completely lost at one point (...). One thing led to another, I let myself be completely swallowed, that's when I started drifting at home as well, and I let myself be eaten by the project. (Hugo)

Even if these coaches are looking for a compatibility between coaching life and family life, the game seems to be lost in advance. These coaches find themselves in the situation explained by Dixon and Bruening ${ }^{1}$ where professions with a strong commitment lead to confusion between work life and family life, or even make it impossible to interrupt work to accommodate the family context. Despite questions about this, coaches explain that reducing engagement in their profession is not an option in the context of a race for performance ${ }^{28}$ and an acceleration of the pace of life: ${ }^{15}$ "I I wondered if I could do otherwise. So I observed the other directors of the other nations. Those who succeed are very active. If you slow down, it's over'" (Pierre). This is also what this coach says: "You have no choice otherwise you are no longer in your job as a coach of the French team" (Fabrice). The profession of high-level coach requires a large amount of time invested. ${ }^{10,65}$ Another coach highlights this dilemma of reconciling work and family life by explaining that he wants "not to suffer, again, on the personal family level (...). What really put me at the bottom of my life is my divorce" but that "at the same time I am a competitive and international (...) addict" (Christophe). These results had already been highlighted by Graham and Dixon who explained that in the world of high-performance sport, working many hours and being addicted to work had become commonplace. ${ }^{43}$ Dependent on this passion, the family balance suffers: "I divorced after 6 months in the job" (Mickaë 1); "I have family problems, my wife has left" (Serge). Time management ${ }^{15}$ dedi- cated to professional passion and family life is complex and these coaches, whether women ${ }^{1,2,52,54}$ or men, ${ }^{43}$ are not satisfied: "'[i.e. sport] is my passion. The negative side is essentially family. I have a baby who is a few months old, a 7-year-old daughter, I'm divorced. It's complicated' (Jean). This group of coaches believe their profession requires a personal sacrifice as a base to succeed. ${ }^{1}$ This is why, when a choice has been made between work and family life, the results suggest that these coaches interviewed have done so for the benefit of their work, resulting in a certain cost to the family. ${ }^{41}$ 
Family life as protection for an even greater commitment. Family life, and more specifically parenting, ${ }^{56,66}$ is part of coaches' thinking about professional engagement. This coach explains that she does not see herself doing this job for very long: "if only for my family, even for my pace of life (...). If the organization doesn't change, I will go until 2020"' (Brigitte). This is how some coaches explain that they temporarily stopped their duties, for personal organizational reasons: "I resigned (...) because I had to take care of my little one', (Serge), as well as for emotional reasons. For example, one coach explains how the arrival of her first child upset her professional and family balance:

And when my maternity leave ended, I lived it - it's still moving to say it, to talk about it - I lived it very badly. Because it didn't only mean going back to work like a lot of women would do in the world, because it meant separating from my child. In other words, in April I went back to work, fifteen days later I went abroad for 12 days (...) very, very painful. So much so that it made me sick. (Lou)

After the birth of her first child, this coach had a very bad experience of resuming her professional life because she felt that she could not, at the same time, be strongly involved in her profession as a coach and in her new role as a mother: ${ }^{13,57}$ "But my colleagues continued to work, in the evening there were meetings, things and I didn't have the necessary time for my daughter. I was going through it really badly' (Lou). This is why this coach decided to change, temporarily, her professional life: "I decided that it's enough, that I've suffered enough (...) I decided that I've suffered enough and that I want other children and that I'll never go through this again. Never, ever again' (Lou).

Others choose to change their functions and assignments. For example, Vincent decided to train, no longer top-level athletes but promising ones, especially to limit the number and duration of trips away from his family: "It also wears out the family, you shouldn't overdo it. (...) Don't mess with that' (Vincent). For these coaches, having children has created a temporary limit in the management of engagement in professional life, unlike some models identified in the world of sport:

In sport, this model proposes that if a sport manager or participant wants to maximize work satisfaction, he or she should minimize family involvement. The most effective family structure for minimizing involvement outside of work is one with no children. (Dixon and Bruening, ${ }^{1}$ p. 235)

This is confirmed by one of the coaches interviewed: She explains she does not have children: "No little ones, not ready, too selfish still!' (Sandra). These findings raise the issue of the continuation and duration of coaching careers. ${ }^{9}$ And this particularly because balance between professional and personal life is not always easy to maintain: ${ }^{41}$ "You invest even more, even more until you can no longer (...) because if you do not set these limits, others will suffer (...) it impacts your whole life, even though in a season you don't do much" (Sandra). Parent coaches may experience higher levels of guilt and exhaustion. ${ }^{52,53}$ This coach explains:

Of the $150 \%$ I should have put at home, I was $30 \%$, I wasn't there. That's what I told my son: 'I actually discovered you when you were 8.' When my ex-wife and I got divorced. 'Yes from age 0 to 8 I saw you, but in the end I don't remember your first steps.' It was not my priority when he should have been one of my priorities. (Fabrice)

The implementation of strategies to ensure a professional and family balance. A few of the 41 coaches interviewed have an atypical profile, like Ali. He explained, as did the other coaches interviewed, that he quickly realized that his job could be time-consuming. But in the professional and family balance established at the beginning of his career, he stands out from other coaches. He claims to have identified three essential elements to be implemented to preserve this balance: (i) restricting his missions around athletes by limiting the time spent investing in other tasks, such as administrative tasks, ${ }^{10}$ (ii) not travelling to all competitions and (iii) compensating periods of over-commitment by periods entirely devoted to the family:

I did it early enough and I may not have been caught up in a work spiral. So I tried to set a limit. And, since I'm married, and the father of a little guy, I'm careful, in the evening at 6:30 p.m. I try to say 'stop'. In any case, I impose myself to stop, not precisely at the same time, but I organize myself to finish, to have a small compensation for the weekends of absence and to be with my family not too late. Otherwise I could very well take an athlete who arrives not too late and train him until 8 pm-9pm, but I'm not sure it would be beneficial. And, in any case, if I want to last in the long term it won't work like that, so I'm careful with that (.. .). Yes, I think I found it, over a year, really over the year I found my balance. (Ali)

Other coaches testify to these articulations between professional and family balance:

The good thing is that I can take a lot of days off when I come back from competition, I take a few days off. 
As for vacation, I still manage to take three weeks in the summer, that's good. (Sé bastien)

These strategies echo those identified in high-performance athletes. ${ }^{15,46,67}$ In addition to satisfying the family environment, family time is a time of personal regeneration. In this sense, the family is an indirect protection against overwork. In addition, a coach explains that he takes a week's total rest before major competitions, in order to anticipate fatigue. He says that coaches must "manage their own schedules. (...) You have to feel privileged and you have to feel like a boss: You have to have the opportunity to say no", (Benô̂t).

Guarantors preserving the family life of other coaches. The survey therefore reveals several possibilities for coaches to protect themselves from professional over-commitment through family life: (i) thinking about the organization and articulation of time both over the long career time and the short daily time, (ii) postponing family projects, (iii) withdrawing temporarily, or changing jobs to reduce professional commitment when family requires it.

The life partner also plays an essential role: Among coaches who feel that they have preserved their family life, many have a spouse from high-performance sport, who knows the constraints and may then accept them more easily:

Although my wife is a former high-performance athlete and she knows the high-performance level and everything, it is not always easy. (.. .) You need to have a wife who already understands. She used to be an athlete so that's easier. (Sé bastien)

Some colleagues or coaches can also play a role in this search for professional and family balance. Although they are a minority, some of the coaches interviewed position themselves as guides or even guarantors protectors - of the family life of the national coaches with whom they work, failing to have been able, according to some of them, to benefit from it:

Today we are $100 \%$ to have divorced, you know (.. .) if I could have done without it, I would have done without it (.. .). It is my responsibility (.. .). I think that it would have deserved some support (.. .). A support that was not enough because it was swallowed by my passion (.. .) I should have been big but (.. .) I see that not many of us are great at all this. (Hugo)

Most of the coaches interviewed expressed disappointment that they had not been able to benefit mentoring ${ }^{68}$ even possibly from organizational support ${ }^{69,70}$ to be better able to preserve their family life. As shown by Reade et al. ${ }^{68}$ about the training of coaches, the latter, for lack of time, learn most often from other coaches, through more or less formal mentoring. In the same way, these coaches want their colleagues (Pierre, Michaë 1, Hugo, Arnaud) to learn how to limit their time spent at work. This is what this coach sets up, especially during training camps:

Not all coaches come. Some can thus decompress and trust the coaches who will take care of the training camp (.. .). This does not mean that coaches are happy not to go to the camps. They are disgusted but it is for their own good because they are sometimes blinded by their passion. (Arnaud)

Lou is one of them too. She explains that she managed to preserve her professional and family lives - by temporarily leaving her job for another, less exciting one: "On the other hand, as I had held a much higher position, it was a little frustrating", (Lou). Since she is now a coach again, she wants to do everything possible to facilitate the preservation of other coaches' professional and family balance.

This ability to regulate passion is difficult for coaches but seems to be facilitated when the collective, e.g. integrated support team ${ }^{71}$ gets involved: for example, coaches who have themselves become managers of coaches. ${ }^{62}$ But, as the results of this survey show, this balance is also a fragile collective construction. ${ }^{62}$ The emergence of these managers raises the question of the need to institutionalize accompanying processes for coaches, to help them maintain their wellbeing, without falling into other conflicts. ${ }^{72}$

\section{Conclusion}

The analysis of the results highlights differences in the management of coaches' professional and family life. ${ }^{21}$ Without falling into the trap of universalism; however, the analysis of the results shows that all the coaches interviewed have one thing in common: They do not consider stopping their careers, ${ }^{70,73}$ as they have such a strong passion for their profession. It is even the opposite, as this coach puts it: "If I were asked to stop today, it would be terrible" (Christine). On the other hand, this does not mean that no high-level French coach has ever wished or even made the choice to stop their professional career. ${ }^{36}$ The lack of data to this effect is related to the constitution of the sample of this study where the coaches interviewed were still active at the time of the survey.

In a context of race for performance, this study also shows how passion for this profession can create vulnerability in coaches, even situations of misery. 
This raises the problem of career duration, career change and vocational training of high-level coaches. The results show that the institution has a supportive role to play in addressing social and structural constraints $^{3,70}$ of coaches through their aspirations and needs, among others. The question of responsibilities of French sports institutions as regards the difficulties encountered by coaches remains to be developed. At this stage of analyzing the data collected, it turns out that the lack of recognition can generate a form of resentment that leads to judging and reconsidering working conditions a posteriori:

When you realize that going to a training camp costs you money because you have to have childcare and you don't even have compensation for it, you start thinking ... At first, you don't come for the money but gradually you see that it is important and then you tell yourself that the federation has the best part, that it benefits from it. (Franç ois)

But this institutional investment is essential to prevent coaches from feeling they have to choose between their professional and family lives ${ }^{42,74-76}$ and to limit the risks of burnout. ${ }^{70,75,77-79}$ For example, institutionalizing support to coaches, preserving a certain flexibility in the organization of their working time $^{69}$ and facilitating the care of their children by being more family friendly are factors that sports organizations can no longer neglect because they have a direct impact on their performance and therefore that of their athletes. More generally, this study also provides input into reflections on the limits of new forms of human resources management that promote accountability, autonomy and self-fulfillment. ${ }^{80}$

\section{Declaration of conflicting interests}

The author(s) declared no potential conflicts of interest with respect to the research, authorship, and/or publication of this article.

\section{Funding}

The author(s) disclosed receipt of the following financial support for the research, authorship, and/or publication of this article: This research was funded by the Sports Department of the French Ministry of Sports.

\section{ORCID iD}

Hé lè ne Joncheray(D) https://orcid.org/0000-0002-7048-0658

\section{Notes}

a. By high-level coach we mean coaches preparing athletes for the Olympic Games.

b. According to a Report of the Court of Auditors entitled “'L'É tat et le mouvement sportif: mieux garantir l'intérê général" ("The State and the sports movement: how to better guarantee general interest'), published in January 2018.

\section{References}

1. Dixon MA and Bruening JE. Perspectives on workfamily conflict in sport: an integrated approach. Sport Manage Rev 2005; 8: 227-253.

2. Dixon MA and Bruening JE. Work - family conflict in coaching I: a top-down perspective. J Sport Manage 2007; 21:377-406.

3. Kay T. The work-life balance in social practice. Social Policy Soc 2003; 2: 231-239.

4. Chambliss D. La banalité de l'excellence: enquê te ethno- graphique sur la stratification (de la natation) et les nageurs olympiques. Sci Soc Sport 2010; 3: 45-75.

5. Demaziè re D, Ohl $F$ and Le Noé O. La performance sportive comme travail. Sociol Travail 2015; 57: 407-421.

6. Stevenson CL. Becoming an "international athlete: making decisions about identity. In: Inside sports. London: Routledge, 1999, pp.86-95.

7. Duffy P, Hartley H, Bales J, et al. Sport coaching as a 'profession': challenges and future directions. Int J Coach Sci 2011; 5: 93-123.

8. Nordmann L and Sandner H. The diploma coaches study at the Coaches Academy Cologne of the German Olympic Sport Federation - current state and new developments. Int J Coach Sci 2009; 3: 69-80.

9. Purdy LG, Kohe GZ and Paulauskas R. Coaches as sport workers: professional agency within the employment context of elite European basketball. Sport Educ Soc 2019; 24: 195-207.

10. Gilbert W, Cô te J and Mallett CJ. Developmental paths and activities of successful sport coaches. Int $J$ Sports Sci Coach 2006; 1: 69-76.

11. Donoso-Morales D, Bloom GA, et al. Creating and sustaining a culture of excellence: insights from accomplished university team-sport coaches. Res $Q$ Exerc Sport 2017; 88: 503-512.

12. Mallett $\mathrm{CJ}$ and Cô té J. Beyond winning and losing: guidelines for evaluating high performance coaches. Sport Psychol 2006; 20: 231-221.

13. Inglis $S$, Danylchuk $K$ and Pastore $D$. Multiple realities of women's work experiences in coaching and athletic management. Women Sport Phys Activity J 2000; 9: 1-26.

14. Kelley BC. A model of stress and burnout in collegiate coaches: effects of gender and time of season. Res $Q$ Exerc Sport 1994; 65: 48-59.

15. Burlot F, Richard R and Joncheray H. The life of high level athletes: the challenge of high performance against the time constraint. Int Rev Sociol Sport 2016; 53: 234-249.

16. Knoppers A. Explaining Male dominance and sex segregation in coaching: three approaches. Quest 1992; 44: 210-227.

17. Messner MA. It's all for the kids: gender, families, and youth sports. California: University of California Press, 2009. 
18. Theberge N. Managing domestic work and careers: the experiences of women in coaching. Atlantis: A Women's Studies J 1992; 17: 11-21.

19. Chalip L. Role conflicts in a coaching subculture. In: Hinchcliff $\mathrm{J}$ (ed.) The nature and meaning of sport in New Zealand. Auckland: University of Auckland, 1978, pp.62-65.

20. Cheeseman J. Coaching as a third job. In: Developing the female coach and coaching the elite female athlete. Canberra: Australian Sports Commission, 1992, pp.1314.

21. Christensen MK. Outlining a typology of sports coaching careers: paradigmatic trajectories and ideal career types among high performance sports coaches. Sports Coach Rev 2013; 2: 98-113.

22. Hinojosa-Alcalde I, André s A, Serra P, et al. Understanding the gendered coaching workforce in Spanish sport. Int J of Sports Sci and Coach 2018; 13: 485-495.

23. Inglis $S$, Danylchuk $K$ and Pastore D. Understanding retention factors in coaching and athletic management positions. J Sport Manage 1996; 10: 237-249.

24. Mercier R. Supporting women who coach and have families. Can J Women Coach 2000; 1: 1-9.

25. Schenewark J and Dixon MA. A dual model of work family conflict and enrichment in collegiate coaches. J Issues Intercoll Athlet 2012; 5: 15-39.

26. Julhe S and Honta M. L'articulation travail-famille chez les conseillers techniques sportifs: situations asymé triques entre hommes et femmes. Sociologie 2012; 3 : 341-357.

27. Lemieux C and Mignon P. E tre entraineur de haut niveau. Sociologie d'un groupe professionnel entre marche' du travail fermé et marche' du travail. Paris: Institut National du Sport, de l'Expertise et de la Performance, 2006.

28. Ehrenberg A. Le culte de la performance. Paris: Hachette, 1991.

29. Freidson E. Les professions artistiques comme dé fi à l'analyse sociologique. Revue Franç aise Sociol 1994; 27: 117-135.

30. Menger PM. Portrait de l'artiste en travailleur. Métamorphoses du capitalisme. Paris: Le seuil, 2002.

31. Goffman E. The presentation of self in everyday life. New York: Doubleday, 1959.

32. Goffman E. Asylums: essays on the condition of the social situation of mental patients and other inmates. Garden City, New York: Anchor Books, 1961.

33. Goffman E. Stigma: notes on the management of spoiled identity. New York: Simon \& Schuster Inc. Touchstone Edition, 1986.

34. Birrell S and Donnelly P. Reclaiming Goffman: Erving Goffman's influence on the sociology of sport. In: Sport and modern social theorists. London: Palgrave Macmillan, 2004,pp.49-64.

35. Paugam S. Pour une dé finition sociologique de la pré car- ité professionnelle. Politiq Soc 2002; 61: 15-29.

36. Mazerolle SM, Bruening JE, Casa DJ, et al. Work-family conflict, part II: job and life satisfaction in National Collegiate Athletic Association Division I-A certified athletic trainers. J Athlet Train 2008; 43: 513-522.
37. Mazerolle SM, Pitney WA, Casa DJ, et al. Assessing strategies to manage work and life balance of athletic trainers working in the National Collegiate Athletic Association Division I setting. J Athlet Train 2011; 46: 194-205.

38. Loriol $\mathrm{M}$ and Leroux $\mathrm{N}$. Le travail passionné. L'engagement artistique, sportif ou politique. Toulouse: Erè s, 2015.

39. Goffman E. Interaction ritual: essays on face to face behavior. New York: Routledge, 2005.

40. Fletcher D and Scott M. Psychological stress in sports coaches: a review of concepts, research, and practice. J Sports Sci 2010; 28: 127-137.

41. Greenhaus JH and Powell GN. When work and family collide: deciding between competing role demands. Organiz Behav Hum Decis Process 2003; 90: 291-303.

42. Ryan TD and Sagas M. Relationships between pay satisfaction, work family conflict, and coaching turnover intentions. Team Perform Manage: An Int J 2009; 15: $128-140$.

43. Graham JA and Dixon MA. Coaching fathers in conflict: a review of the tensions surrounding the work-family interface. J Sport Manage 2014; 28: 447-456.

44. Graham JA and Dixon MA. Work-family balance among coach-fathers: a qualitative examination of enrichment, conflict, and role management strategies. J Sport Manage 2017; 31: 288-305.

45. Demeslay J and Le Noé O. Des noms et des nombres. Ré gimes ré putationnels et horizons temporels dans le sport de haut niveau. Terrains Travaux 2015; 1:203-222.

46. Julla-Marcy M, Burlot F and Le Mancq F. Socialisations temporelles dans le sport de haut niveau. De la mấ trise du chronomè tre à la mâ̂ trise du temps. Temporalités [En ligne] 2017; 25. DOI: 10.4000/temporalites.3713.

47. Greenhaus JH, Bedeian AG and Mossholder KW. Work experiences, job performance, and feelings of personal and family well-being. J Vocation Behav 1987; 31: 200-215.

48. Rosa H. Social acceleration: a new theory of modernity. New York: Columbia University Press, 2013.

49. Layte R. Divided time: gender, paid employment and domestic labour. Aldershot: Ashgate Publishing, 1999.

50. Rosa H. Alienation and acceleration: towards a critical theory of late-modern temporality. Malmö : NSU Press, 2010.

51. Durand-Bush N, McNeill K and Collins J. The self-regulation of sport coaches: how coaches can become masters of their own destiny. In: The psychology of effective coaching and management. Nova Science Publishers, 2015, pp.217-265.

52. Bruening JE and Dixon MA. Work-family conflict in coaching II: managing role conflict. J Sport Manage 2007;21:471-496.

53. Bruening JE, Dixon MA and Eason C. Coaching and motherhood. In: Women in sports coaching. London: Routledge, 2016, pp.95-110.

54. Dixon MA and Sagas M. The relationship between organizational support, work-family conflict, and the job-life satisfaction of university coaches. Res $Q$ Exerc Sport 2007; 78: 236-247. 
55. Altfeld S, Mallett CJ and Kellmann M. Coaches' burnout, stress, and recovery over a season: a longitudinal study. Int Sport Coach J 2015; 2: 137-151.

56. Carlson DS. Personality and role variables as predictors of three forms of work family conflict. $J$ Vocation Behav 1999; 55:236-253.

57. Bruening JE and Dixon MA. Situating work-family negotiations within a life course perspective: insights on the gendered experiences of NCAA division I head coaching mothers. Sex Roles 2008; 58: 10-23.

58. Roderick M. The work of professional football. London: Routledge, 2006.

59. Le Noé O. Veni, vidi, lusi. L'é nigme du loyalisme des judokates de haut niveau. Sociol Travail 2015; 57: 536558.

60. Renfree G and Kohe GZ. Running the club for love: challenges for identity, accountability and governance relationships. Eur J Sport Society. Epub ahead of print 9 June 2019. DOI: 10.1080/16138171.2019.1623987.

61. Bertrand J. Se pré parer au mé tier de footballeur: analyse d'une socialisation professionnelle. Staps 2008; 82: 29-42.

62. Loriol M and Spielmann L. Quand la passion s'emmê le. De l'investissement de soi à la souffrance dans une MJC, scè ne de musiques actuelles. In: Le travail passionné. L'engagement artistique, sportif ou politique. Toulouse: Erè s, 2015, pp.117-151.

63. Lumpkin $\mathrm{K}$ and Anshel M. Work addiction among intercollegiate sports coaches. J Sport Behav 2012; 35: 406-432.

64. Hobfoll SE. The influence of culture, community, and the nested-self in the stress process: advancing conservation of resources theory. Appl Psychol 2001; 50: 337-421.

65. LaVoi NM. Women in sports coaching. London: Routledge, 2016.

66. Byron K. A meta-analytic review of work-family conflict and its antecedents. J Vocation Behav 2005; 67: 169-198.

67. Burlot F and Julla-Marcy M. Rythme de vie et accé lé ration du travail sportif: le dé fi de la performance de haut niveau face à la contrainte du temps. In: @ la recherche du temps. Individus hyperconnectés, société accélérée: tensions et trans- formations. Toulouse: Eres, 2018, pp.281-293.

68. Reade I, Rodgers W and Spriggs K. New ideas for high performance coaches: a case study of knowledge transfer in sport science. Int J Sports Sci Coach 2008; 3: 335-354.
69. Bentzen M, Lemyre PN and Kenttä G. Development of exhaustion for high-performance coaches in association with workload and motivation: a personcentered approach. Psychol Sport Exerc 2016; 22: 1019.

70. Kilo RA and Hassmé n P. Burnout and turnover inten- tions in Australian coaches as related to organisational support and perceived control. Int $J$ Sports Sci Coach 2016; 11: 151-161.

71. Durand-Bush N, Collins J and McNeill K. Women coaches' experiences of stress and self-regulation: a multiple case study. Int J Coach Sci 2012; 6: 22-43.

72. Kohe GZ and Purdy LG. In protection of whose "wellbeing?" Considerations of "clauses and a/effects" in athlete contracts. J Sport Soc Issues 2016; 40: 218-236.

73. Cunningham GB, Sagas M and Ashley FB. Occupational commitment and intent to leave the coaching profession: differences according to race. Int Rev Sociol Sport 2001; 36: 131-148.

74. Dixon MA, Bruening JE, Mazerolle SM, et al. Career, family, or both? A case study of young professional baseball players. NINE 2006; 14: 80-101.

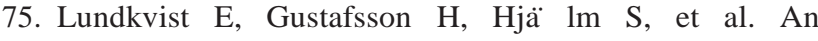
interpret- ative phenomenological analysis of burnout and recovery in elite soccer coaches. Qual Res Sport Exerc Health 2012; 4: 400-419.

76. Pastore DL. Male and female coaches of women's athletic teams: reasons for entering and leaving the profession. J Sport Manage 1991; 5: 128-143.

77. Altfeld $\mathrm{S}$ and Kellmann M. Burnout of coaches. In: Psychology of burnout: New research. Hauppauge, NY: Nova Science, 2013, pp.193-207.

78. Altfeld S, Schaffran P, Kleinert J, et al. Minimising the risk of coach burnout: from research to practice. Int Sport Coach J 2018; 5: 71-78.

79. Short SE, Short MW and Haugen CR. The relationship between efficacy and burnout in coaches. Int $J$ Coach Sci 2015; 9: 37-49.

80. Boltanski L and Chiapello E. Le nouvel esprit du capitalisme. Paris: Gallimard, 1999. 